\title{
Decolonising African vernacular-rooted sculptures of selected contemporary Nigerian and South African artists
}

\section{Sule Ameh James -}

Department of Visual Arts,

University of Pretoria,

South Africa
Journal of Decolonising Disciplines

Volume 2, Issue 2 (2020)

eISSN: 2664-3405

DOI: https://doi.org/10.35293/jdd.v2i2.686

\section{Abstract}

My paper presents a decolonial reading of African vernacular-rooted sculptures of selected contemporary South African artists (Pitika Ntuli and Sinethemba Ngubane) and Nigerian artists (Yemi Ijisakin and Fidelis Odogwu) and compares them. I draw the conception of decolonisation from the school of thought of Natural Synthesis. Although vernacular arts were produced in indigenous or traditional African art contexts, there are several forms of vernacular art practices still jostling for space with canonical modes in contemporary art in various African contexts. In this paper, however, I argue that the contemporary representations of cultural imagery and symbols from indigenous cultures or urban areas in South Africa and Nigeria are deemed vernacular as a rethink in theorising works rooted in African lived experiences. Therefore, they are not a continuation of traditional African art or any of the canonical modes. To this end, the contents and contexts of two South African and two Nigerian artists' works were analysed using formal analysis, cultural history methodology, and insights gained from interviews. The works echo the unity of mineworkers in resisting post-democratic oppression, the ignorance of families that kill intersex children instead of allowing them to live, the irony of embrace in contemporary Nigerian societies, and the cultural value for enduring male and female marriage in Nigerian cultures. The comparisons reveal differences in the discourse of contemporary issues and artistic trends that contribute to global contemporaneity.

Keywords: Decolonisation, Contemporary, African, Vernacular, Cultural Imagery, Art Practice 


\section{Introduction}

Since the dawn of the postcolonial era in the late 1950s to the mid-1960s, when most African nations became independent, scholars have engaged in the decolonisation of thought and philosophy. Although a very restrictive understanding of decolonisation is limited to the use of the term in the struggles for political independence (OkekeAgulu 2006; Pissarra 2009), contemporary decolonisation is taken beyond the formal transfer of power. In light of this, in the African art canon, artists, curators and scholars have in different ways engaged in decolonising projects in theory and practice by identifying gaps, arguing thoughts, creating and curating multiple artworks from the continent and diaspora. One of the reasons, as Gaisang Sathekge argues, is to 'address the way, black artists, within art historical canon, have been stereotyped and their subject matter and style understood only within the framework of terminology ... while their white counterparts dominated and continue to dominate the industry economically' (Makgato 2015: 1). ${ }^{1}$ Sathekge's argument reveals the experience of racial categorisations of African art and not Western art, which is borne out of the cultural bias of the West against Africa.

What is decolonisation? Decolonisation as a social process might be viewed as a mode of self-actualisation for African people, suggesting the need to reconstruct African philosophy. It is a form of acknowledging historical wrong and perhaps writing to address such wrongs See 'Decoloniality and justice a priori' by Kumalo and Praeg (2019). Similarly, according to Okeke-Agulu, decolonisation is 'the process of dismantling the ideological foundations of colonisation' (Visona 2016: 272). These definitions suggest that the very essence of colonisation, which was also a social process, is the reason for decolonisation. This is because the process of colonisation began with the destruction or stereotype of African art and symbols and the eradication of sacred sites in indigenous cultures. But in turn, introducing and entrenching colonial cultures and values to the colonised. Thus, to truly decolonise, there must be a rediscovery and refashioning of thoughts and ideological foundations to reflect the perspective of the colonised. This view is also expressed by African art curator Naomi Beckwith, who points out that 'we have to de- and re-construct notions ... as we think afresh about the representations of those we want included

1 See 'The "so called" emerging black artists:' exhibition review by Khehla Chepape Makgato as he quotes the curator of the exhibition Gaisang Sathekge. 
in the historical record' (Grant \& Price 2020: 16). Although the decolonisation of historical wrongs in the discourse of African art demands the deconstruction and reconstruction of knowledge, it might also include self-defining terms that are adapted to avoid stereotypes.

To this end, some decolonisation projects include a critique of the exhibition Africa Explores by Susan Vogel, which opened in New York in 1991. Friedel (2017: 1) argues that while 'Vogel's goal was to communicate the artworks through the experiences and viewpoints of African artists ... this intention did not become clear in the exhibition'. She added that 'her definitions were actually quite random, outdated and narrow'. She further observes that the exhibition was 'developed in and by Western institutions and therefore had nothing to do with the perspectives of the artists from Africa' Similarly, curator Simon Njami, in his international travelling museum exhibition Africa remix: Contemporary art of a continent (2004-2007), challenged the curatorial approaches of earlier international exhibitions of artwork from Africa such as Susan Vogel's Africa Explores. Njami (cited by Cooper-Rodger 2005: 1) argues that 'the aim of "Africa Remix" was to put together an exhibition that highlighted the deep motivation behind African creativity and to put a stop to a series of misconceptions and myths about the continent'. Unlike Africa Explores, a recent exhibition Prete-moi Ton Reve curated by Yacouba Konate in Dakar hones in on African artists in Africa rather than African artists in diaspora, and the artworks on show were produced by 30 African artists. Rather than exhibiting in Berlin, London, Paris and New York, as Keener (2019: 1) notes, 'the exhibition takes a panAfrican show and brings it to the local level, making it more accessible to various communities while highlighting the nuances of African cities'. Such a pan-African perspective to curating exhibitions reflects an attempt at decolonising curatorial practices.

Similarly, in a review of contemporary art presented by African artists at the Dakar Biennale, Thomas McEvilley criticised and stereotyped them and those of the Johannesburg and Cairo Biennales as 'Kitsch Modernism'. By 'Kitsch' he meant, 'a recreation that lacks the sense of authenticity that the style had when it was alive and dynamic'. Although the key issues his argument raises against those works involve authenticity and modernism, it can be argued that such accusation is more applicable to Western art as it encountered and appropriated art from other cultures which it either destroyed or disrupted. It must be abundantly clear that Africa could not have skipped modernity and become immediately post-modern, thereby absolving 
itself of the sense of belatedness. Besides, does modernity always have to be based on Western precepts? In my view, modernity - as a Western construct - is not a wheel in art, without which art in other locations cannot move at all.

In this article, I focus on decolonising African vernacular-rooted sculptures of selected contemporary Nigerian and South African artists, which were produced between the years 2007 and 2016. Although the time frame is short, it is aimed at examining the cultural imagery and symbols (vernacular) they represented and the ideas conveyed. I draw the conception of decoloniality from the school of thought of Natural Synthesis proposed by Uche Okeke. This entails the conscious, critical deployment of the fresh aesthetic and technical expertise learned from the art classes to synthesise mainstream Western abstraction and fundamental African aesthetic sensibilities (Okeke-Agulu 2006; Owerka 1985). To this end, this essay seeks to establish how Natural Synthesis is expressed in the individual works of two South African sculptors, Pitika Ntuli and Sinethemba Ngubane, and two Nigerian sculptors, Yemi Ijisakin Olaolu and Fidelis Odogwu Eze. By looking at the imagery they portrayed in sculptures, I argue that their modes of portrayals within the context of Natural Synthesis are divergent even though the imagery they represent could still be deemed African vernacular-rooted. Although 'vernacular' refers to that which is domestic and indigenous (Gupta \& Adams 2018), in this paper the term is adopted as rethinking in theorising the representations of cultural imageries that are rooted in Africa as part of contemporary decolonisation politics. The terminology is not a stereotype, a signification of any indigenous or traditional African art or its continuation, but attempts to gain insight into the analysis of depicted cultural images that are deeply rooted in African lived experience. In this regard, I argue that this is significant because, while decoloniality has provoked considerable studies and discussions, there is little discourse about it on contemporary sculptures rooted in Africa. Through this focus, even while the paper contributes a wide insight into art historical analysis on the representations of cultural imageries from selected Nigerian and South African art to the global contemporaneity; it establishes how such images reflect Africa experiences. The following questions will guide the analysis: What cultural imagery did the artists represent in their African vernacular-rooted sculptures? What African identities are constructed in the sculptures of Nigerian and South African artists? What themes and ideas does the analysis of the works convey to the audience?

In doing this, I highlight the research methodology adopted in the analysis, 
attempt a developmental history of Nigeria and South Africa as nations, then provide a brief history of art practices and education in both countries, contemporary African art practices and decolonising the African vernacular-rooted sculptures. This is followed by a comparative analysis of their works, ideas relayed, and a conclusion.

\section{Research methodology}

This paper combines art historical methodologies for the reading of the artworks produced by contemporary artists from both countries. Hannula, Suorauta and Vaden (2005: 38) argue that, when aiming to understand the world, it is possible to combine methods as basic premises for perception. Therefore, I combine visual hermeneutics theory, formal analysis, and cultural history methodologies in exploring the context and contents of their African vernacular-rooted artworks. Formal analysis is employed in this study to confront the visual elements of each work and their relation to the indigenous or urban context they reflect, and how they convey the intended meanings to viewers. The cultural history is employed to focus on narrating a history that is Africa-centred in both countries. Given the fact that forms are not sufficient in understanding and interpreting artistic expressions, the contents of each depiction will also be explored to highlight the ideas conveyed. Lastly, the paper presents a comparative analysis of the contemporary African vernacular-rooted sculptures of the selected artists. Tolia-Kelly and Morris (2004) propose that, to understand the categories of the present, there is a need to return to cultural history. Additionally, the study employed field research on each of the four artists, and their responses to interview questions helped authorise claims and interpret their selected sculptures.

\section{Development of Nigeria and South Africa as nations}

Although Nigeria and South Africa, as nations, emerged from the same colonial administration, they unfolded differently. Whereas Nigeria gained independence from colonialism in 1960, with cultural unification of three major ethnic groups - Yoruba, Hausa, and Igbo - and over 300 other ethnicities, South Africa, after suffering from 'settler colonialism' (Manaka 1987: 11), was 'granted independence from Britain in 1961, [but] sank ever deeper into racial definitions of difference' under apartheid (Nettleton 2011: 13). South Africa was liberated in 1994, when she 
entered into her postcolonial future as a multi-cultural and multi-racial country. This political development is not without consequences for the black South Africans, as they were affected negatively in several ways including being denied access to art education during apartheid.

\section{A brief history of art practices and education in South Africa and Nigeria}

As history reveals, before the coming of missionaries and colonial administrators to Africa, there was a practice of cultural productions known as traditional art in many indigenous African societies. For instance, in Manaka's (1987: 9) words, 'Rock Art is one of the earliest South African indigenous forms of artistic expression. It is one of the earliest forms of traditional painting and graphic art which is pivotal to the study of the historical development of South Africa'. Other traditional art forms include the Tsonga freestanding figurative sculpture employed 'as didactic tools in the initiation institutions of such groups as the Pedi, Tsonga, and Venda' (Nettleton 1988: 48) and the Zulu free-standing sculptures that 'are most often called "ancestorfigures," despite the fact that there is no evidence whatsoever that the Zulu ever used these objects in any such context at all' (Nettleton 1988:49).

Similarly, art practices in traditional Nigerian settings are known from Nok, Benin, Igbo-Ukwu and Ife pieces, among others. These traditional sculptures are indigenous to Nigeria and the different cultures that made them. While most of these art traditions date back to the pre-colonial era, Wangboje (2005: 1) argues that 'Nok terra-cottas, consisting of human and animal figures and believed to have been made between $500 \mathrm{BC}$ and $200 \mathrm{AD}$ is/are reputed to be the oldest sculptures in Africa, South of the Sahara'. New forms of cultural productions emerged in Africa in the 19th century, yet the emergence saw differences in South African and Nigerian environments concerning significantly different access to art education and opportunities to practise and to be acknowledged as an artist during the modern era.

As Pissarra (2009: 1) notes, with 'the non-directive educational pedagogies of expatriate founded art schools in Africa in the 20th century', modern African artists were introduced to a different art practice from the traditional art forms of the precolonial era. Soon after apartheid was institutionalised in 1948, her program of 'separate development' was extended to the education sector. As a result, in 1949, a commission was set up to modify the content and syllabi of the school system for indigenous black South Africans (Ebewo \& Sirayi 2018). The consequence of 
this policy for the black South Africans is seen in the lack of access to formal art education in schools or as an extramural or recreational activity during apartheid. However, some black artists were fortunate enough to have been trained through art workshops at Polly Street Art Centre, established in Johannesburg in 1949, and the Evangelical Lutheran Arts and Crafts Centre at Rorke's Drift, established in the early 1960s. As Mario Pissarra (2011: 183) notes, these community art centres were funded by organisations and countries that were opposed to apartheid in South Africa. These art centres, especially the Polly Street Art Centre, were established to provide significant visual art education opportunities for modern black artists who were effectively locked out of formal art education by apartheid (Pissarra 2011). As Friedman (2011:29) argues, these centres inspired a corpus of work that achieved considerable critical acclaim and inspired future generations of artists. This contrasts with the situation in Nigeria, where the teaching of art was introduced into schools in the 1920s by Aina Onabolu (1882-1963).

In 1920, Onabolu 'left for London to have, for the first time, some formal training in art in St. John's Wood College' (Oloidi 1986: 113). He returned to Nigeria in 1922 after obtaining a diploma and began to teach art formally part-time in many secondary schools around Lagos. But in 1926 he realised the workload was too much for him to handle alone, so he met with the Education Department and requested a European artist, and in 1927 Kenneth Murray was sent (Oloidi 1986). While the introduction of the formal teaching of art in Nigerian schools was focused on the formalistic composition of art, a strong emphasis was made on culturisation, which must reflect traditional African values and reinstate African artistic heritage in modern art (Oguibe 2002; Oloidi 1986). Thus, modern African/Nigerian artists, in Oguibe's (2002: 244) words, 'began to enter and appropriate cultural forms of modernity at the turn of the 19th century'.

A major reason for the perception of modern and contemporary African art as the same as historical African art, despite its academic mode of depiction, is perhaps that 'understanding African art in its own context was of no real consequence when one was really interest[ed] in furthering a western discourse' (Pissarra 2009: 2). It is for this reason, as Oloidi (cited by Oguibe 2002: 246) notes that 'the colonial authorities failed to distinguish between the classical African forms which they condemned as heathen and Aina Onabolu's work. Yet Onabolu's artworks were modern art practices in Nigeria. So, although his works were of a different context of engagement with African heritage, they were considered as the continuation of traditional African art 
practice. But modern and historical African arts and artists had very little in common (Nettleton 2011; Pissarra 2009). While modern artworks were designated inferior in Nigeria, the artistic expressions of Pablo Picasso, in which he adopted motifs or elements from historical African forms, were/are read as modern art.

Similarly, the artworks of many black artists who emerged in the art scene in the 1960s in Johannesburg and Durban, despite having no formal art training, were stereotyped as 'township art'. Nettleton (2011: 15) argues that 'they were all dubbed "township" artists not only because they mostly lived in the segregated townships located outside the white urban areas of South Africa's apartheid towns and cities, but also because they engaged with issues of social and political oppression and exclusion' Given that the term was used as a stereotype, she critiqued it, noting that 'the term "township art" should have been discarded, because it sets up false dichotomies between artists based on race and class'. Besides, such racial categorisation is problematic as it reduces all townships to uniform geography and the experiences of all black artists to one communal life, even though they are diverse.

Although art education was introduced in Nigerian universities in the 1950s and 1960s, in South Africa, the indigenous blacks never had access to art education in high schools and universities until 'the end of apartheid and the formation of the Government of National Unity (GNU) in 1994, [when the] need [arose] for a paradigm shift - for a new dispensation to address the imbalances of the past' (Ebewo \& Sirayi 2018: 83). In addressing the imbalances of the past, there was the demand for equity and access to education, which suggests the 'freedom to pursue a career in any field of study that will contribute to the development of South Africa. No subject in the school curriculum is to be marginalised' (Ebewo \& Sirayi 2018: 85). It was this paradigm shift that allowed black South Africans access to art education.

However, the use of stereotyping terminology did not end in the 20th century; it continues in the 21st century, with works of contemporary African artists who articulate cultural imagery and symbols being stereotyped as outside the 'normative contemporary art standards' (Malatjie 2011: 10), although such works are contemporary African cultural productions of artists trained on European and American models. As a result of the stereotype, they are considered unworthy or undeserving of art historical narrative, even though their modes of practice are different from those of the traditional African art context. It can therefore be argued that 'The discourse of decoloni[s]ation enables us to evaluate the liberation of art in Africa through the notion of neo-colonialism' (Pissarra 2009: 5). Even so, modern 
and contemporary African artists have not only been decolonising their art practices but have demonstrated to the colonialists through their works that Africans have the ability to make creative renditions like the West (Oloidi 1986: 115).

\section{Contemporary African art practices}

The field of contemporary African art is implicated in the present and relies heavily on the representations of artists on the continent and in the diaspora who have evolved independent personal and artistic styles. To establish the scope of contemporary African art, Enwezor and Okeke-Agulu (2009: 11) note that 'contemporary African art denotes a field of complex artistic production, research, interpretation, and a repository of rich intellectual discovery at the intersection of the shifting models of cultural, political, social and epistemological analyses in which Africa is meaningfully interpellated'. From their argument, the scope of contemporary African art is not limited to the artistic production but the writings that interpret and establish how deeply rooted the cultural productions are in African heritage and experience. The artistic productions are, however, marked with different styles, subjects, and themes.

Furthermore, in contemporary African art, artists adapt the synthesis of formal language which they fuse with African sensibility in a highly creative manner. ${ }^{2}$ As Owerka (1985: 78) argues, this is because 'a number of these artists have received a solid art training, most often on European or American models. They have adopted techniques and media either unknown or rarely employed in traditional African arts'. Owerka's argument suggests that traditional African art is a distinct mode of cultural production from contemporary sculptures, even though the former artistic productions might have influenced the latter. They reflect the lives of Africans rooted in South African and Nigerian contexts. The periods of production of traditional African art and contemporary African sculptures represent two distinct time frames (Nzewi 2013). Also, the stories these artists tell in their contemporary sculptures are indicative of different contexts rather than a continuation of traditional art.

2 See Carolyn Owerka’s article contemporary African art. 


\section{Decolonising African vernacular-rooted sculptures}

The analysis of the sculptures begins with the work of Pitika Ntuli (b. 1942), who had art training in Europe and America. In aligning his portrayal of African vernacularrooted imagery with the idea of Natural Synthesis, his works show identification with and a greater sensitivity to the social space of black South Africans. This is demonstrated in an installation sculpture entitled Marikana (2012/13) (Figure 1). The title Marikana introduces a site where striking miners were massacred in August 2012 in the North West Province of South Africa. The mixed-media construction was installed in an open space in South Africa shortly after the grievous display of power by the police. The formal elements of the installations reveal three vernacular imageries constructed with diverse found objects that reflect some of the striking mineworkers before they were massacred. Despite being a post-apartheid installation, it presents a thematic thrust that would have been linked to apartheid, but for the fact that the horror of apartheid has been officially laid to rest.

The imagery on the left side, in Ntuli's (2017) words, represents 'the leader of the striking miners'. His head is constructed with the gearbox of a car, perhaps to signify how effective he was at thinking and directing the affairs of the miners. On this head are constructed the facial features, looking at viewers confidently with the mouth agape, while possibly articulating the reasons for the strike action. The green plastic container covering him signals, as Pijoos (2017: 1) notes, a subjective identity of 'the image of Mgcineni Noki aka The Man in the Green Blanket. Thus, Pijoos's identification does not merely establish the identity of the leader, but his African identity and that of other miners. Such use of a plastic medium to convey images in Ntuli's work, although different, seems to be reminiscent of South African artist Willie Bester and Nigerian artist Dilomprizilike. For Ntuli, the adoption of found objects in creating installations is not limited to the plastic containers but includes exhaust pipes and other scraps, as evident in the other two imageries. His use of found objects, as Koloane (2010: 135) points out, shows 'uncanny utilisation of motor parts characterised by linear projections of entangled exhaust pipes and other tubular articulations, always offbeat in nature'. Through this mode of representation, Ntuli worked 'within the recycling process to interpret discarded objects in order to give them a new life and meaning' (Makgato 2015: 1). Aside from the analysis of the formal structures of these installations, a return to cultural history might help in contextualising the experience. 


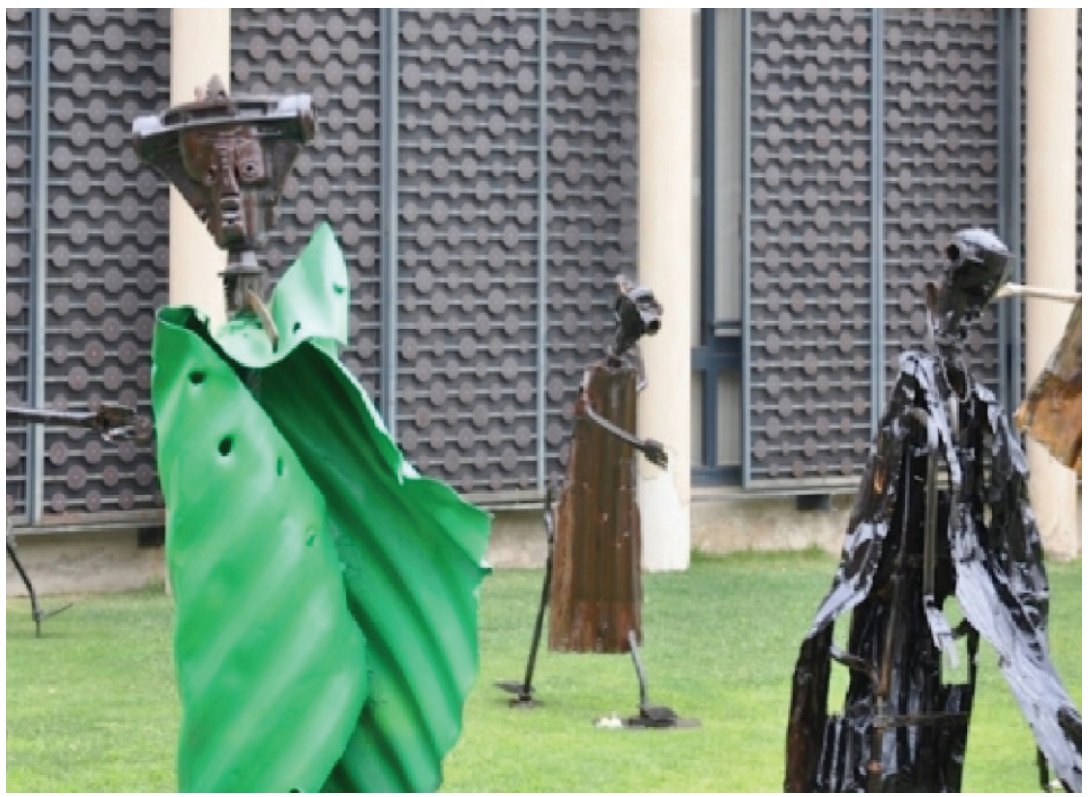

Figure 1: Pitika Ntuli, Marikana, 2012/13. Mixed media, and varying sizes. Artist's collection (Courtesy of Ntuli)

Although the formal language of this installation may be read as the influence of his Western training, this does not imply that installation in African art is a Western ideology. History reveals that installation is not new to Africa, as the oldest example of documented conceptual art dates to 1230 AD, in the Mema Kingdom of Mali. It was a collection of a broken old basket filled with guinea fowl feathers, battered calabashes, and bits and pieces of rubbish, which Sogolon Diata-Sundiata (founder and emperor of the Kingdom of Mali) had laid at the feet of the King of Mema, Mussa Tankara. It was a symbolic payment for land to bury his mother, who died while they were both in exile in the Kingdom of Mema.

Although the Marikana incident happened in post-apartheid South Africa, it recalls a similar massacre that took place on 21 March 1960, at Sharpeville near Johannesburg. An article at South African History Online (n.d.) states that 'the African National Congress (ANC) and Pan Africanist Congress (PAC) started new campaigns against the hated pass system. So, on the morning of 21 March 1960, 5000 people gathered at the Sharpeville police station to start the campaign'. Though 
they were angry, they were peaceful and quiet, when suddenly the police opened fire on them without warning, which led to the deaths of 69 people. It also invokes the Soweto uprising of 16 June 1976, but in this context, the mineworkers were making a demand for a wage increase, which the management rejected. After a series of demands and clashes at the site, on 16 August 2012, the South African police, who were invited, opened fire killing 34 workers. The work demonstrates anger directed at a post-democratic government for a display of ideology that appears to align with a colonial or apartheid mode of governance. Despite this argument, the idea is deeply rooted in the African experience of resistance as a form of contemporary decolonisation. In this interactive installation, the philosophy that seems to guide Ntuli is one that speaks out rightly in condemnation of the killing of the miners, instead of exploring dialogue.

Although the aim of Ntuli's oeuvre resonates with the plight of those massacred at Marikana, it hints at a protest art that ran a course of rejection or, at best, critical ambivalence. In this regard, it serves as 'a dynamic medium' of cultural weapon in a public space for viewers to relate to in resistance to the government and wealthy miners. It evokes engagement with the past and future of places that deserve more intelligent and critical outcry from audiences on the subject of the massacre in a decolonised society. While Ntuli's vernacular sculptures reflect the idea of condemning the massacre of protesting mineworkers, the next portrayal draws attention to another form of killing - that of black children born intersex. However, both works reveal artistic narratives on a society or nation that is at war with her people. The next work is by Sinethemba Ngubane (b. 1991), trained at Durban University of Technology. In the Natural Synthesis of African vernacular-rooted imagery, she takes an unusual path in coming to terms with her cultural identity, as she focuses on depicting the imagery of distorted intersex babies. She chose this image rather than the portrayal of cultural practices to act as a voice for the voiceless babies and to make a sociocultural commentary on the need to accept them in African families. This is revealed in the installation sculptures Rebirth of bio-politics (2015) (Figure 2). Introducing this work during an interview, Ngubane (2017) claimed that 'the title is given to these distorted bodies because it reveals an aspect in biology that is contested and debated upon'. Ngubane's claim that there is debate in science regarding the existence of intersex babies is arguable because research conducted in 1970 revealed that 'intersex syndromes have been recognised in South Africans' different racial groups' (Grace 1970: 3). 
This establishes the fact that they exist not only among the blacks and whites but among other races in South Africa. What characterises intersex? The biological condition of 'intersex broadly refers to a variety of conditions that [do] not correspond to typical definitions of male and female' (Jenkins \& Short 2017: 92). Ngubane (2017) states that, when 'I discovered that it is a social reality in South African communities that have not been explored in art, I decided it will be my focus'. While it appears she is filling a gap in visual culture with her rendition of distorted intersex bodies, similar depictions that explore distorted and mutilated bodies are evident in contemporary South African art. The works of Penny Siopis suggest massacre not only of children but of women. Similarly, mutilation was evident in Lien Botha’s images. But Ngubane's depictions reference different stages of mutilation in eight distorted bodies. The bodies displayed are exactingly rendered as if they were zoological specimens.

Although different degrees of decomposition are exemplified in the formal elements of the installations, there appears to be a visible inconsistency in the level of decomposition in the same body. For example, while the second vernacular imagery from the left shows a high level of decomposition on the body, the head appears like that of a child asleep. Perhaps the variation is not just to show decomposing bodies but coded indictments of the tortures inflicted upon real human beings. From the left side of the installation, the first body is represented from the back view with a head that appears to be in normal condition, but the body is distorted. The head of the second baby is depicted with all the facial features, reflecting a sleeping baby, whereas the remaining parts of the baby are mutilated. The third and sixth imageries show varying degrees of mutilation, revealing the rib bones painted white, while all other parts show maimed arms and legs. Although the fourth, fifth, seventh, and eighth vernacular symbolisms are alike, the stages of mutilation suggest that they are beyond recognition. 

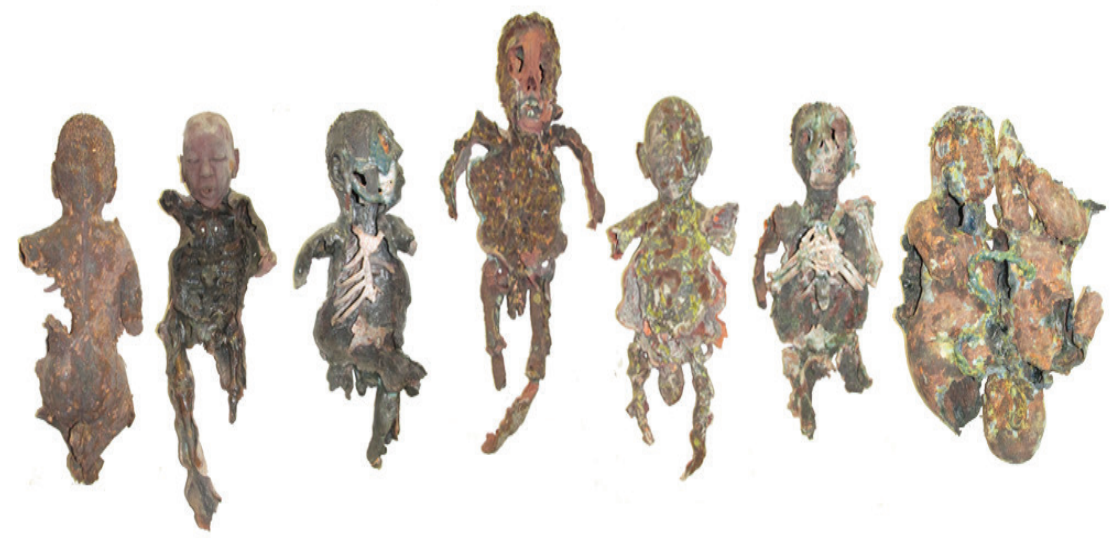

Figure 2: Sinethemba Ngubane, Rebirth of bio-politics, 2015. Terra-cotta Installations, $84.5 \mathrm{~cm} \times 184 \mathrm{~cm} \times 20 \mathrm{~cm}$ (Courtesy of Ngubane).

It may be argued that the last two imageries on the right were buried together; this is implied from their positions, which evoke conjoined babies with the seventh's head placed upward, while the head of the eighth is placed downwards. Ngubane's primary medium used to execute these eight distorted bodies of young African children is clay, but they were allowed to dry and later burned to signify terracotta sculpture. This is possibly the reason there appears to be an intersection of aesthetics of glaze colours fused into each of these sculptural installations, to create the effect of mutilation of the bodies. The historical narrative, in Grace's (1970: 3) view, reveals that while it may be contentious, intersex was first discovered in South Africa at the Cape between 1817 and 1827. While there are no known statistics of people living with the condition of intersex in South Africa, perhaps because African cultures do not have equivalent words, in the 2010s, an intersex activist Sally Gross (cited by Husakouskaya 2013: 12) suggested that the population of intersex is 'between 45000 and 90000 South Africans'. It is, however, possible that a significant population of people are living with intersex conditions without medicalisation.

Ngubane (2017) notes, 'I knew someone who was demoralised and dejected because he was intersex, after he had an operation performed on him to cover the female genital. Unfortunately, it failed, and eventually, he committed suicide'. In Ngubane's (2017) view, 'my works are aimed at correcting societal attitude towards 
intersex. In rural black communities, such babies are looked upon as abnormal, so they are killed. This hints at the poor treatment of families dealing with intersex. In addition, it echoes 'societal beliefs in a rigidly dimorphic approach to sex' (Jenkins \& Short 2017: 97). It might be argued, that this depiction evokes the harder job of treating intersex. But Ngubane's depiction demonstrates that, in African metaphysics, the dead remain with the living, even though the depictions seek to make sense of the debased conditions and contest them through art. Through this work she reflects on the African experience in contemporary South African environments and the African voice for humanity.

While the vernacular sculptures of Ntuli and Ngubane reflect on some of the social issues of killings of mass protesters and black intersex babies in South Africa, a shift is made in the work of Yemi Ijisain Olaolu (b. 1957), trained at Obafemi Awolowo University, Ile-Ife. In his decolonisation of imagery, he reflects on the cultural practice of embrace between a male-and-female couple. This is evident in the African vernacular-rooted stone sculpture entitled Embrace (2009) (Figure 3). Although it is an abstract stone sculpture, the subject matter of embrace signals the response of someone in love, at the sight of their beloved. It also hints at the expression of love as the embrace of another. But in this depiction, Ijisakin (2017) draws attention to an ironic embrace, where 'an individual with evil motive would come to embrace his supposed victim while hiding his evil intentions until eventually, he harms the unsuspecting victim. While ill motives may be expressed through the ironic cultural practice of embrace, not all embraces typify danger.

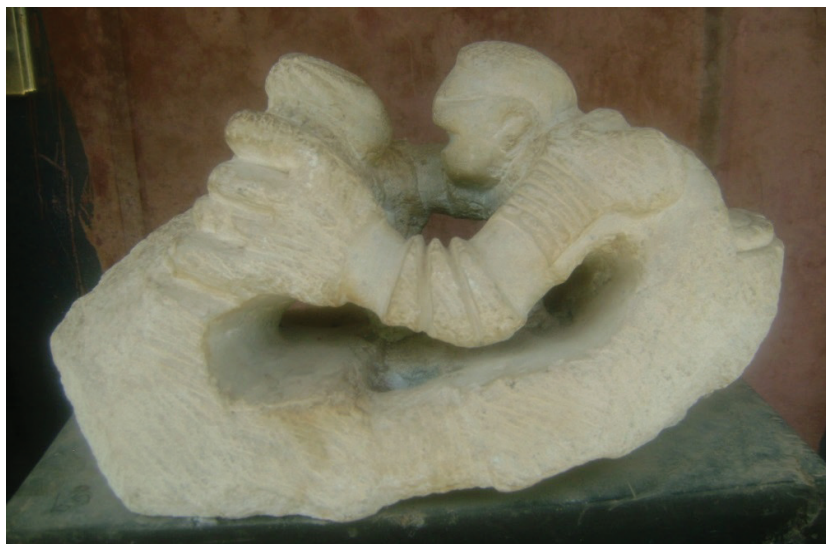

Figure 3: Yemi

Ijisakin, Embrace, 2009. Stone, $8 "$ x $12 "$ x $5 "$. Artist's collection. (Photographed by Sule James). 
The sculpture depicts a small abstracted vernacular imagery in the round and reveals an African man and a woman entangled with warm hands. It seems to emphasise the emotional expressiveness of the art. However, to create a distinction in the formal structure of the symbolism, the imagery on the left side reveals an African woman with plaited hair. The braiding does not merely adorn the face and head, but aids in shaping the head. Her hands are entangled with those of the African man, hinting at a continuum of one hand rather than distinct and separate renditions of female and male hands. But at the point of intersection of both hands are several elements that appear like bangles, used as ornaments for female personal adornment. Their legs seem to be entangled as well, possibly to convey the idea of the embrace which joins them. Rather than an embrace, however, the reading evokes a posture of a couple dancing because the mode of embrace does not include body contact. It might be argued that their dynamic formal interaction suggests that they are about to begin dancing, rather than embrace. On the other hand, their posture invokes fear of being embraced, which gives a clue to a process of struggle. If we accept this reading, the depiction is in dissonance with an embrace as it rather evokes an attempt to resist embrace.

The cultural history sees 'couple imagery [evident] in numerous African sculptural traditions [and it] constitutes an ideal of cultural refinement and elegance designed to enhance the prestige' of the bond (LaGamma 2004: 28). It also demonstrates that, in African cultures, twin imagery is depicted 'because this best represents that desired state of completeness, the merging of male and female' imagery (Peek 2008: 23). Therefore, even though Ijisakin's sculpture is a peculiar contemporary rendition, it does not only draw attention to similar depictions of seated female figures embracing in 19th- or 20th-century headrest from the Luba society in African art but also appears to have been influenced by its mode of rendition (LaGamma 2004; Peek 2008). Although the date of this African art coincides with colonial contexts in Africa, it might be assumed that it gives an idea of the period it was made, as it may predate the 19th century. It can be argued that such African art did not have colonial influence because when the missionaries began outreaches in Africa in the 19th century, they viewed and rejected African art forms on the premise that they were heathenistic (James 2021). The philosophical view that guided Ijisakin's work is sensitivity to security matters and the need for vigilance to stay safe in contemporary Nigerian societies. In Ijisakin's (2017) view, the aim narrates a 'contemporary redefinition of embrace, where a husband embraces his wife but afterward sells her 
or sacrifices her for money rituals or [a] terror suspect embraces his victim only to detonate the explosive afterward, leaving the scene littered with remains of human flesh'3.

It might be argued that although people are kidnapped for ritual killings, for fame, money, protection, power and success, not all instances may involve the embrace. However, the ambivalence in embrace comes from the unsuspected terrorist who uses ironic humour to attack and detonate a bomb. While the sculpture relates the need for security consciousness, one must not be suspicious of people in general. On another level, the work hints at completeness, which only the act of making love can temporarily accommodate. The aim also echoes duality in contemporary African vernacular-rooted sculpture.

The last focus is on the work of Fidelis Odogwu Eze (b. 1970), a metal sculptor who trained at Auchi Poly, Edo State, Nigeria. In his Natural Synthesis of imagery, he comes to terms with the cultural practice of male-and-female marriage in Yoruba culture. It is titled Together forever (2015) (Figure 4). This title hints at a social construction that introduces marriage union or togetherness between a male-andfemale couple. The stylised metal relief references an African man and woman adorned in African dress forms of the same colours and patterns signalling aso ebi, worn to attend events or ceremonies in Yoruba culture in southwestern Nigeria. Their adornment with traditionally styled garments with African flair and similar decorative motifs evokes not just the notion of double but a couple.

The medium employed by Odogwu in this contemporary African artistic expression is flat metals and slim iron rods cut to different shapes and welded together. The construction of the groom's head suggests that the artist folded flat metals into a round shape to represent the head, while a traditional Yoruba styled cap is welded on top of the head and a red beaded necklace around his neck. The formal content shows different flat metals shaped and used to create the African garment worn by this groom, who appears joined with his bride in a traditional marriage ceremony. Although two long metal strips were constructed in front, they flow from the neck of the groom, draping gracefully and bothering an elongated triangle in the middle, embellished with linear and geometric designs that symbolise embroidery.

3 Boko Haram, which became a threat to lives of Nigerians in 2009, continued to adopt new strategies when seeking to kill more people in the northern part of Nigeria. Sometimes adult or child members of the sect, with bombs strung around their bodies, forcefully embrace a victim in the crowd and then detonate the bomb, killing the suspect, the victim and others in close proximity. 
It is an example of embroidery that is found on the front and back of a voluminous tailored robe referred to as 'agbada' in Yoruba culture. At the top left side of the garment is a stylised triangle bothered by slim iron rods for reinforcement, separated from the long strip with a dark space in between, which represents the graceful folds of a drapery garment. Directly below this triangle is another elongated triangle that symbolises the lower part of the garment. Though the depiction reveals different linear designs used in embellishing the two sides of the groom's garment, it hints at the aesthetic structure of contemporary African dress. In constructing the right side that borders the bride, several design motifs were depicted from the top to the lower part of the garment.

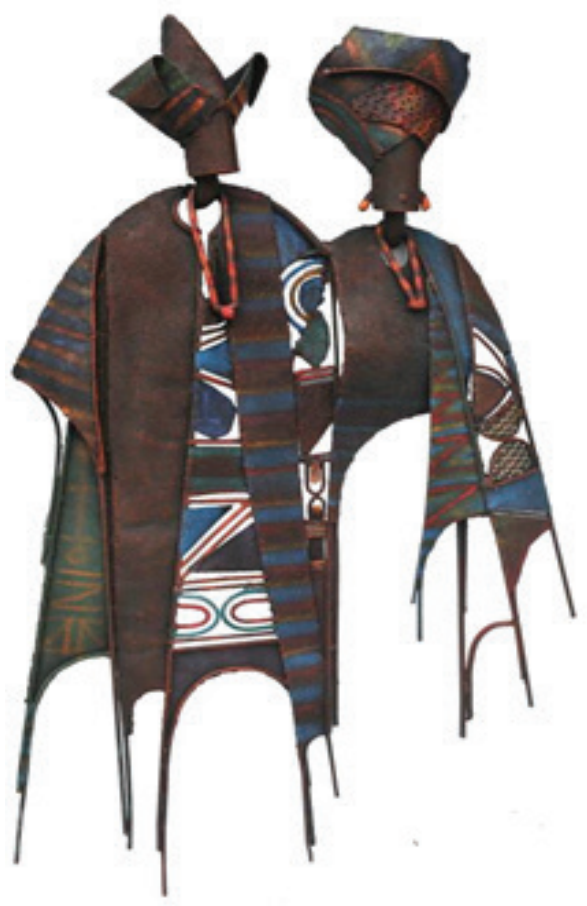

Figure 4: Fidelis Odogwu, Together forever, 2015. Welded Metal, 33" x 18" (Courtesy of Odogwu).

Furthermore, though the formal elements of this bride reflect a female Yoruba visual form, the rendition suggests the use of flat metals cut to suitable shapes and sizes, twisted, folded, and welded together to create the 'gele' (headgear) constructed on her head, and embellished with colourful patterns. She is rendered without facial features, except for a red spot that symbolises her mouth. The ears are signified by the projecting red earrings welded onto both sides of the bride's head. A red beaded necklace that compliments the earrings and outfit drapes from her neck to her bust. Strips of metal that depict the bride's wrapper are folded and placed over her left shoulder but drape forward. The wrapper is embellished with different linear decorative motifs, the designs hinting at 'embroidery [made with] creative straight line $[\mathrm{s}]$ and curvilinear patterns on a Yoruba woman's traditional 
wrapper (iro) and blouse (buba)' (Akinwumi 1998: 55).

Although the present experience represents mature adults rooted in Yoruba culture, such visual narrative could be given context and identity when presented from the point of view of the cultural history of double or couple in Yoruba art. Marriage is as old as the first couple, Adam and Eve. As Denzer (1994: 3) argues, in 'pre-colonial Yoruba society ... marriage was a necessary condition of adulthood. All young women and men were expected to marry when they reached the appropriate age - women in their twenties, men in their thirties'. Nonetheless, such marriage was 'traditionally monogamic [although] the wealthy indulged in polygamy' (Johnson quoted by Denzer 1994: 4). To demonstrate an example of this idea of monogamy without divorce in Yoruba art, history reveals that 'Edan Osugbo consists of male and female figure - representing a community's founders and an alliance of opposites ... joined at the sum by a chain' (LaGamma 2004: 26). The chain that links these elements is significant because it underscores the idea of a sacred bond that unites male and female couple, which must not be broken. Therefore, reading this depiction communicates the idea of a bond that unites a man and his wife in contemporary indigenous Yoruba culture, especially through marital vows.

This aim, in Odogwu's (2017) view, signifies a 'marriage vow that must be till death separates the partners in Yoruba culture. However, this does not negate such value among other cultures in Nigeria. The aim of this depiction evokes a contemporary narrative of love. On the other hand, it signifies not merely twinness and completeness but the bond that exists between a male-and-female couple. Alternatively, it invokes the marriage vow a couple makes but soon sacrifices on the altar of divorce because of marital strife and instability. Hence, Odogwu's philosophy is guided by the traditional practice of marriage between a male and female, who must live together until death separates them.

\section{Discussion and comparisons of the works and ideas}

In demonstrating contemporary decolonisation in sculptures, while the works of Nigerian artists frame African identities with forms, symbols rooted in myriad contemporary cultural practices, South African art reflects a more generic response to African identities. These works show the Natural Synthesis in some of the responses of African cultural productions to diverse contemporary issues of mass killings of protesters and ritual killings of babies and adults, which may not be new 
to Africa. But to demonstrate that these are new modes of depictions, Ntuli, in a peculiar style, adopts found objects as the media for representing his images, whereas Ngubane portrays mutilated bodies of intersex babies. Ijisakin portrays a couple's ironic bond. However, Ijisakin's bond is different from the male and female bond in Odugwu's sculpture.

A comparison of the aims in Pitika Ntuli's African vernacular-rooted installation sculpture entitled Marikana and Sinethemba Ngubane's installations Rebirth of biopolitics reveals similarities in echoing social issues of murder in post-apartheid South Africa. But they differ in the ideas of murder that they reflect in each one's context and content. While Ntuli's depiction echoes the greed of wealthy mining tycoons as a possible reason for killing miners and hints at a lack of regard for their humanity, the aim in Ngubane's rendition gives clue to what Dreger (2006: 73) calls 'poor treatment of families dealing with intersex' babies in rural areas of South Africa. In Ngubane's (2017) view, 'they are seen as abnormal children, so they are not merely killed but their bodies are used for rituals' Conversely, the comparative analysis of the aims that unfolds from Yemi Ijisakin's vernacular-rooted sculpture Embrace and Fidelis Odogwu's Together forever unfolds similarities in the aims of bond and duality between couples.

Still, they differ because the bond in Ijisakin's portrayal symbolises, in Ijisakin's (2017) words, 'an evil embrace from someone who appears friendly but for the wrong motive, either to detonate a bomb or use the victim for ritual in contemporary Nigerian society', while the aim in Odogwu's depiction symbolises the marriage bond between a male-and-female couple in Yoruba culture in southwestern Nigeria. It is against the mores of Yoruba culture for a man or woman who reaches marriageable age to remain single, so they marry even if the man is impotent (Oti \& Ayeni 2013). Thus, the cross-national comparison of the aims that unfold from the depictions of South African and Nigerian artists reveals differences. The differences exist because the experiences reflected on in the South African renditions reveal killing, perhaps because of greed and exploitation of miners for cheap labour, and family intolerance of intersex babies for the sake of rituals. Conversely, the aims in the depictions of the Nigerian artists reflect male and female marriage bonds, even though some evil practices against unsuspecting spouses may be identified.

In conclusion, while it has been established that their contemporary African vernacular-rooted sculptures are not indigenous art objects, it might be argued that the mere fact that contemporary Nigerian and South African artists represent 
cultural imagery in sculptures is an ideology that speaks to the decolonisation of their art practices, which are aimed at relaying new ideas. The styles contemporary artists from both countries use in articulating cultural imagery in their sculptures and the media they employ further invokes a different mode of artistic production from the ones used in traditional African arts. Hence, the use of any language in stereotyping their contemporary art practices as a continuation of the art produced in precolonial African societies is a faulty interpretation. Rather, their works should be understood not merely as coming to terms with their African roots but as responses to some of the concerns in both countries. For instance, the vernacular sculptures of the two contemporary South African sculptors reflect on the trauma and unjust killings of black South Africans engaged in peaceful protest, and the evil of muti ritual killings associated with intersex babies. In contrast, the works of the two Nigerian artists narrate the socio-cultural values of male-and-female marital bonds. Thus, these artists demonstrate through their contemporary sculptures different ways of engaging with cultural imagery that reflect contemporary social issues in decolonised societies in South Africa and Nigeria.

\section{Bibliography}

Akinwumi, T.M. (1998). High fashion in African dress machine embroidery: A futuristic model for the Lagos garment industry. USO: Nigerian Journal of Art, 2(1\&2): 53-63.

Cooper-Rodger, K. (2005). 'African Remix': contemporary art of a continent. Cambridge Letters, 1(3): 1-3.

Denzer, L. (1994). Yoruba women: A historiographical study. The International Journal of African Historical Studies, 27(1): 1-39.

Dreger, A.D. (2006). Intersex and human rights: The long view. In S. E. Sytsma (Ed.), Ethics and intersex (pp. 73-86). Springer.

Ebewo, P.J. \& Sirayi, M. (2018). Curriculum transformation in a postapartheid South African university: The arts faculty, Tshwane University of Technology. Africa Education Review, 15(2): 82-95.

Enwezor, O. \& Okeke-Agulu, C. (2009). Contemporary African art since 1980. Damiani Bologna.

Friedel, J. (2017). Exhibition histories: Africa explores.

https://www.contemporaryand.com/magazines/africa-explores/ 
Friedman, H. (2011). Beauty, duty and dissidence ideology and art in the heyday of apartheid. In L. van Robbroeck (Ed.), Visual century, South African art in context (II, 1945-1976).

Grace, H.G. (1970). Intersex in four South African racial groups in Durban. BSc Thesis, University of Natal.

Grant, C. \& Price, D. (2020). Decolonizing art history. Association for Art History.

Gupta, P. \& Adams, T. (2018). Vernacular photography from Africa: collections, preservation, dialogue. Critical Arts, 32(1): 1-12.

Hannula, M., Suorauta, J. \& Vaden, T. (2005). Artistic research, theories, methods and practices. University of Gothenburg.

Husakouskaya, N. (2013). Rethinking gender and human rights through transgender and intersex experiences in South Africa. Agenda, 27(4): 10-24.

Ijisakin, Y.O., artist, University of Ife. (2017). Interview by author. [Transcript]. 10 June. Ile Ife.

James, S.A. (2019). African modernism: A comparative study of resistance in the modernist art of Nigeria and South Africa. Critical Interventions, 13(2-3): 228253.

Jenkins, T.M. \& Short, S.E. (2017). Negotiating intersex: A case for revising the theory of social diagnosis. Social Sciences and Medicine, 175: 91-98.

LaGamma, A. (2004). Echoing images, couples in African sculpture. The Metropolitan Museum of Art, New York.

Keener, K. (2019). Exhibitions: Prete-moi Ton Reve continues to make waves in Dakar. Art Critique. https://www.art-critique.com/en/2019/12/prete-moi-tonreve-hits-dakar/

Koloane, D. (2010). Pitika Ntuli, magic and transmutation of objects. In Pitika Ntuli, scent of invisible footprints-the sculptures of Pitika Ntuli (pp. 135-144). Pretoria: University of South Africa Press.

Kumalo, S. \& Praeg, L. (2019). Decoloniality and justice a priori. Journal of Decolonising Disciplines, 1(1): 1-9.

Makgato, K.C. (2015). 'The 'so called' emerging artists': Exhibition review. ARTAFRICA.

Malatjie, P. (2011). Contested contemporaneity: Reflections on Nelson Makamo's neo-figurative subjects. In Cityscape and Countryscapes, an exhibition by Nelson Makamo at Museum Africa (pp. 8-12). 
Manaka, M. (1987). Echoes of African art, a century of art in South Africa. Skotaville Publisher.

Nettleton, A. (1988). History and the myth of Zulu sculpture. African Arts, 21(3): 48-51

Nettleton, A. (2011). Writing artists into history. Dumile Feni and South African Canon. African Arts, 44(1): 8-25.

Ngubane, S., artist, Durban University of Technology. (2017). Interview by author. [Transcript]. 15 November. Durban.

Ntuli, P, artist, Louis Botha. (2017). Introduction of his works to the author. [Transcript]. 17 November. Sandton, Johannesburg.

Nzewi, U.C. (2013). The contemporary present and modernist past in postcolonial African art. World Art, 3(2): 211-234.

Odogwu, F.E., artist, Universal Studios. (2017). Interview by author. [Transcript]. 19 June. Lagos.

Oguibe, O. (2002). Appropriation as nationalism in modern African art. Third Text, 16(3): 243-259.

Okeke-Agulu, C. (2006). Nationalism and the rhetoric of modernism in Nigeria: The art of Uche Okeke and Demas Nwoko, 1960-1968. African Arts, 39(1): 26-37, 92-93.

Oloidi, O. (1986). Growth and development of formal art education in Nigeria, 1900-1960. Transafrican Journal of History, 15: 108-126.

Oti, A. \& Ayeni, O. (2013). Yoruba culture of Nigeria: Creating space for an endangered species. Cross-Cultural Communication, 9(4): 23-29.

Owerka, C. (1985). Contemporary African art. African Arts, 18(2): 78.

Peek, P.M. (2008). Couples or doubles? Representations of twins in the arts of Africa. African Arts, 41(1): 14-23.

Pijoos, I. (2017, 16 August). Marikana massacre no difference to Sharpeville massacre - AMCU. News24. Retrieved from https://www.news24.com/SouthAfrica/News/ marikana-massacre-no-different-to-sharpeville-massacre-amcu20170816

Pissarra, M. (2009). Decolonising art in Africa: Some preliminary thoughts on the relevance of the discourse on decolonization for contemporary African art, with particular reference to post-apartheid South Africa. https://asai.co.za/ decolonising-art-in-africa-some-preliminary-thoughts-on-the-relevance-ofthe-discourse-on-decolonization-for-contemporary-african-art-with-particularreference-to-post-apartheid-south-africa/ 
Pissarra,M.ed.(2011).Isolation, distanceandengagement, South Africanartandartistsin the International sphere, in Visual century, South African art in context, 3, 19731992, 180-203. Johannesburg: Wits University Press.

South African History Online. (n.d.) Sharpeville Massacre, 21 March 1960. https:// www.sahistory.org.za/topic/sharpeville-massacre-21-march-1960

Tolia-Kelly, D. \& Morris, A. (2004). Disruptive aesthetics? Resisting the burden of representation in the art of Chris Ofili and Yinka Shonibare. Third Text, 18(2): 153-167.

Visona, M.B. (2016). Chika Okeke-Agulu, postcolonial modernism: Art and decolonization in twentieth-century Nigeria. The Art Bulletin, 98(2): 272-274.

Wangboje, I.S. 2005. Nigerian Traditional Arts, Crafts and Architecture. Retrieved from www.onlinenigeria.com/nigeria-art 